\title{
O słowiańskiej duszy w wierzeniach, kulturze, języku na przykładzie frazeologizmów sztokawszczyzny literackiej
}

Dusza w wielu kulturach i religiach jest kluczowym pojęciem związanym ze sferą wierzeń, filozofii a nawet magii. Według większości religii, dusza jest ulotnym, eterycznym bytem niematerialnym, siłą ożywiającą ciało, trwającą nawet po jego śmierci (zależnie od religii przyjmuje się występowanie duszy u ludzi i ewentualnie u zwierząt). Los nieśmiertelnej duszy po opuszczeniu śmiertelnego ciała i to, jak człowiek może za życia na niego wpływać, jest jednym $z$ fundamentalnych elementów religii wyznających istnienie duszy.

W artykule podjęte zostaną rozważania nad fenomenem duszy w perspektywie kulturowej i językoznawczej. W tym celu najpierw przywołane zostaną pewne wierzenia Słowian przed przyjęciem chrześcijaństwa, w których niezwykle istotny był aspekt życia duchowego człowieka, a duszę starano się opisać przez jej obrazowe przedstawienie. Jest to istotne także dla drugiej części rozważań, analizy językoznawczej sztokawskich frazeologizmów zawierających leksem dusza, które zamieszczone są w słownikach frazeologicznych języków serbsko-chorwackiego, a obecnie serbskiego i chorwackiego. Będzie to głównie analiza semantyczna, skoncentrowana wokół treści i konotacji wnoszonych przez pojęcie dusza do omawianych związków frazeologicznych.

Pojęcie duszy jest bardzo często znaczeniowo i etymologicznie utożsamiane z pojęciem ducha. W wielu językach, w tym także w językach słowiańskich, 
etymologia tego słowa nawiązuje do oddechu, tchnienia, powiewu. W języku polskim bliskie genetycznie pojęciu duszy są np. określenia: dech, dusić, zdechnąć, oddychać, dyszeć. Wydaje się więc, iż zgodnie z prasłowiańskim źródłosłowem, była dusza utożsamiana $\mathrm{z}$ oddechem, tchnieniem, a upostaciowieniem jej była przejrzysta, umiejscowiona w ciele materia, którą można wyzionąć i która opuszcza ciało ludzkie po śmierci (pol. wyzionąć ducha). W religiach animistycznych przypisuje się posiadanie duszy, czasami ducha zmarłych przodków, roślinom, zwierzętom, minerałom i żywiołom.

Przedchrześcijańskie wierzenia Słowian zakładały istnienie duszy u ludzi i zwierząt, a sama dusza była kojarzona $z$ oddechem jako najbardziej zauważalnym w owych czasach symptomem życia. Dla pełniejszego wyobrażenia tego abstrakcyjnego pojęcia przedstawiano czasem duszę symbolicznie pod postacią ptaka, motyla, świetlika, pszczoły, co miało też zapewne za zadanie podkreślić jej ulotność, lekkość, mogło też stanowić synonim wędrówki. Pojęcia: dusza i duch w Słowiańszczyźnie obejmowały szeroki aspekt życia psychicznego człowieka. W świetle wierzeń człowiek posiadał dwie zasadnicze formy składowe duszy (ducha), których losy po śmierci także były różne:

- dusza jaźni, myśli - określająca stan świadomości (za jej siedlisko uważano głowę);

- dusza życia, oddechu - określająca stan sił życiowych, energii (za jej siedlisko uważano serce lub brzuch) (Gieysztor 1986, 216).

Wierzono w reinkarnację dusz, a właściwie pierwszego z tych dwu pierwiastków duchowych, który mógł powrócić odrodzony na ten świat z krain pozaziemskiego bytu dusz, zwanych Niebieskim Wyrajem, lub też z Drzewa Przodków. Drugi z elementów przenikał na inną płaszczyznę bytowania i zazwyczaj był odsyłany do Nawii - podziemnej krainy, gdzie mógł zjednoczyć się z duchami przodków. Obrządek pogrzebowy Słowian zawiera wyraźne sygnały troski o zapewnienie duszy właściwego jej miejsca po śmierci: z jednej strony ciałopalenie, przejęte $\mathrm{z}$ tradycji wschodniej, powodujące szybkie uwolnienie ducha $\mathrm{z}$ martwych powłok cielesnych i jego łatwiejszy odlot do niebiańskich zaświatów - będących we władzy Peruna, z drugiej zaś pierwiastek chtoniczny, polegający na grzebaniu szczątków i symbolicznym zjednoczeniu się z matką-ziemią, powrót do królestwa słowiańskiego boga podziemi Welesa (Szyjewski 2003, 204).

Na uwagę zasługuje omówienie miejsc, do których trafiały dusze po śmierci. Najbardziej rozpowszechnione określenie to Nawie - mityczne, podziemne miejsce, kraina duchów, nad którą władzę sprawował Weles, symbolicznie opisywane jako zielona łąka, na którą Weles wyprowadza dusze, często oddzielona morzem lub wodami rzek. W żadnym wypadku nie przypomina 
chrześcijańskiego wyobrażenia Piekła, z którym często była mylnie kojarzona. Drugą krainą, do której mogły trafiać dusze, był Wyraj, porównywany często, być może z powodu nazwy lub też umiejscowienia, z chrześcijańskim Niebem, Rajem. Była to bajeczna, niebiańska kraina na końcu Drogi Mlecznej, do której odlatują ptaki na zimę, czasem pod ich postaciami dusze ludzkie i z której przychodzi wiosna. Według niektórych wierzeń Słowian był tylko jeden Wyraj, będący formą zaświatów, miejsca niedostępnego ludzkiej percepcji, a potem, prawdopodobnie pod wpływem mieszania z wierzeniami chrześcijańskimi, dokonano podziału na krainę dolną i górną - na wzór nieba i piekła. Wiązano także te krainy $\mathrm{z}$ obecnym $\mathrm{w}$ wierzeniach i folklorze słowiańskim motywem drzewa kosmicznego. Wyraj niebiański, ptasi lokowano w górnej części, koronie drzewa kosmicznego, na jego straży stał złoty kur lub raróg. Tu powracały dusze ludzkie pod postaciami ptaków, stąd też przy pomocy ptaków (bocianów i lelków latem, kruków - zimą) mogły powracać na ziemię i trafiać do łon kobiecych, by w ten sposób ponownie się odradzać. Tu najprawdopodobniej swoje źródło ma ludowe wierzenie tłumaczące przynoszenie dzieci przez bociana, u Czechów również przez kruka, wronę (powiedzenie wrona zastukała im do okna zwiastujące narodziny dziecka). Dolna, podziemna część drzewa kosmicznego, jego korzenie były miejscem tzw. Wyraju podziemnego, wężowego lub smoczego, było to królestwo dusz zmarłych przodków, które nie miały możliwości powrotu na ziemię (Szyjewski 2003, 77).

W ten sposób obydwa wcześniej opisane pierwiastki duszy ludzkiej po opuszczeniu ciała znajdowały właściwe dla siebie miejsce, z tym że jeden z nich, zwany pierwiastkiem ludzkim, mógł się odradzać, powracać do świata żywych, drugi zaś, zwany pierwiastkiem zwierzęcym, nie miał możliwości reinkarnacji i w podziemnej krainie łączył się z duchami przodków. Słowianie wierzyli, że człowiekowi do życia potrzebne są obydwie dusze, chociaż zdarza się, że jedna z nich może chwilowo opuścić ciało, może to się zdarzyć podczas snu, choroby, połączonej z gorączką i majaczeniem, utraty przytomności, letargu. Gdy obydwie dusze opuszczą ciało, następuje śmierć, czyli odejście ducha, czasem proces ten ulega zakłóceniu. Zdarzyć się może, że jedna z dusz zostaje lub jej odejście jest niepełne, wtedy dochodzi do powstania demona lub półdemona np. strzygi, istot nieprzyjaznych człowiekowi.

Z czasem wyodrębniono jeszcze jeden rodzaj duszy, duszę-widmo, która nazywana była marą, zmorą, widmem lub nieboszczykiem. Nie miała konkretnego umiejscowienia, mogła znajdować się w całym ciele człowieka. Utrzymywał ten duch swoisty kontakt ze światem żywych w taki sposób, że co najmniej raz do roku powracał na ziemię. Należało go wtedy ugościć jedzeniem i piciem, ogrzać, stąd pochodzi zwyczaj obchodzenia świąt zmarłych, 
Dziadów, a także zostawiania pokarmów na grobach, dodatkowego nakrycia dla duchów zmarłych (Gieysztor 1986, 218).

Jak widać, w świetle tych dawnych zwyczajów, dusza w wierzeniach Słowian była pojęciem złożonym, często była animizowana, personifikowana, przypisywano jej cechy i właściwości żywych istot, a więc mogła doświadczać takich uczuć i stanów, jak odczuwanie głodu, zimna, czasem bólu, mogła podlegać działaniom różnych sił, mogła się wzruszyć lub przestraszyć, zostać zraniona, a nawet płakać, piszczeć. Ślady tych dawnych wierzeń zachowały się w języku, szczególnie w jego starszej warstwie - pieśniach ludowych, przysłowiach, frazeologizmach, powiedzeniach. Analizy semantyczne wykazują, że najczęstszym miejscem lokalizacji duszy jest serce, stąd wiele synonimicznych powiedzeń w językach słowiańskich z tymi elementami (lekko na sercu / lekko na duszy). Rzadziej pojawiają się inne organy: żołądek, wątroba, oczy, kości, niekiedy utożsamia się duszę z siłą życiową, energią; organy, które tracą duszę, zamierają, usychają. Interesującym zjawiskiem jest też sposób, w jaki dusza opuszcza ciało. Według wierzeń Słowian dusza wydostaje się z ciała przez usta, dlatego mówi się o ciężko chorych, umierających, że mają duszę na języku, w zębach, gardle, nosie, co doskonale zachowało się w starszych powiedzeniach z terenów Słowian bałkańskich.

Potwierdzeniem rangi pojęcia duszy dla Słowian niech będzie analiza materiału językowego - związków frazeologicznych zawierających leksem dusza, wyekscerpowanych ze słowników serbsko-chorwackich, serbskich i chorwackich, czyli języków literackich obszaru sztokawskiego. Wybór frazeologizmów jako materiału do analizy fenomenu duszy słowiańskiej jest tu celowy, bowiem są one swoistą skarbnicą kultury i wiedzy o danej grupie. Analiza frazeologizmów sztokawskich umożliwia też wskazanie pierwotnych warstw pojęciowych, które nie zostały zatarte przez późniejsze, zróżnicowane kulturowo i religijnie dzieje słowiańskich grup narodowych i etnicznych tamtego regionu.

Pod pojęciem związku frazeologicznego rozumiem: „dwu- lub kilkuwyrazową ustaloną (stałą) konstrukcję językową, której znaczenia nie da się wyprowadzić ze znaczeń i reguł łączenia składających się na nią wyrazów" (EJO 1995, 215), najważniejsze cechy szeroko rozumianego frazeologizmu uwypukla też definicja W. Chlebdy: „frazeologizm jest to utarte połączenie wyrazów, odtwarzane $\mathrm{w}$ mowie w gotowej postaci, o znaczeniu metaforycznym, nie wynikającym z sumy znaczeń składników, obrazowe i wzmacniające ekspresywność wypowiedzi" (Chlebda 2003, 12). Zbieżna z powyższymi określeniami frazeologizmu jest definicja chorwackiej językoznawczyni A. Menac zaprezentowana we wstępie do słownika frazeologicznego języka chorwackiego: „Frazemi su ustaljene sveze riječi koje se upotrebljavaju u gotovu obliku, a ne stvaraju 
se u tijeku govornog procesa, i kod kojih je bar jedna sastavnica promijenila značenje, tako da značenje frazema ne odgovara zbroju značenja njegovih sastavnica. Među važnim odrednicama frazema jesu i njihova ekspresivnost, slikovitost i konotativnost" (Menac, Fink, Venturin 2003, 6).

Materiał językowy wyekscerpowany został ze starszych oraz współczesnych słowników sztokawszczyzny literackiej, w głównej mierze ze słowników frazeologicznych. Głównymi i najbogatszymi źródłami materiału okazały się dwa słowniki frazeologiczne, które dzieli spora różnica czasowa i historyczna - z nowszego z nich (Đ. Otašević, Mali srpski frazeološki rečnik, Beograd 2007; dalej: Ot.) pochodzi 121 przykładów, a ze znacznie starszego, powstałego jeszcze w czasach wspólnego języka serbsko-chorwackiego słownika Josipa Matešicia (Frazeološki rječnik hrvatskosrpskoga jezika, Zagreb 1982; dalej Mat.) pochodzi 127 jednostek frazeologicznych z leksemem dusza. Znacznie mniej tego rodzaju frazeologizmów zawierają pozostałe słowniki - współczesny chorwacki: A. Menac, Ž. Fink-Arsovski, R. Venturin, Hrvatski frazeološki rječnik (Zagreb 2003; dalej: Men.); starszy dwujęzyczny słownik chorwacki: A. Menac, N. Pintarić, Hrvatskosrpsko-poljski frazeološki rječnik (Zagreb 1986; dalej: MPin.) i dwujęzyczny serbski: Z. Kovačević, Srpsko-engleski rečnik idioma, izraza i izreka (Beograd 1991; dalej: Kov.). Sprawdzając obecność frazeologizmów z leksemem dusza w słownikach jednojęzycznych, wzięłam pod uwagę chorwacki słownik V. Anicia, Rječnik hrvatskoga jezika (Zagreb 1998; dalej: An.) oraz serbski Rečnik srpskoga jezika (Novi Sad 2007; dalej: RSJ). Analiza językowa zebranego przeze mnie materiału frazeologicznego nie ma na celu konfrontacji ilościowej i jakościowej między tymi dwoma językami, a jedynie ukazanie bogactwa semantycznego, jakie niesie ze sobą wielowymiarowe pojmowanie duszy w Słowiańszczyźnie. Podaję jednakże źródła leksykograficzne omawianych przykładów w celu pełnego zobrazowania ich zasięgu językowego.

Pojęcie duszy w określeniach o charakterze idiomatycznym, analizowane będzie na czterech płaszczyznach znaczeniowych, co jest odzwierciedleniem sposobu jego funkcjonowania w kulturze narodów słowiańskich:

- dusza jako symbol życia, energii;

- dusza jako symbol dobra;

- dusza jako jako symbol rozumu, umysłu;

- dusza jako symbol, metonimia człowieka (w wymiarze indywidualnym lub zbiorowym).

Krzyżują się tu i zazębiają tradycje przedchrześcijańskie, o ludowej proweniencji, z późniejszymi, zaszczepionymi przez religię i filozofię chrześcijańską, dlatego w analizie pojęcia duszy we frazeologii tak ważna jest konotacyjność, odwołanie do tradycji, pewnych zbiorowych wyobrażeń, co podkreślała A. Menac w swej definicji frazemu. 
1. Dusza jako motor, symptom, wyznacznik życia, ruchu, energii (anime), ożywiający cielesną materię, gdy opuszcza ciało, następuje śmierć, degeneracja, różne sposoby wydostawania się duszy z ciała odzwierciedlone we frazeologii, oddanie momentu śmierci, jako symbolicznego opuszczania ciała przez nieśmiertelną duszę różnymi drogami (usta, język, nos, gardło). Ciężka choroba lub śmiertelne przerażenie, strach, jako momenty graniczne, zbliżone do śmierci, mogące skutkować utratą duszy (pol. mieć duszę na ramieniu 'bać się czegoś, być przerażonym'):

biti s malom dušom 1. 'biti teško bolestan' - 'być ciężko chorym'; 2. 'veoma uplašen' - 'być bardzo przestraszonym' (Mat., Ot.),

boriti se (odeliti se, rastajati se) $s$ dušom 'umirati, biti na samrti' - 'umierać' (Mat., Men., Ot., RSJ),

čuvati nekome dušu 'biti kraj nekoga ko je na samrti' - 'być przy umierającym' (Mat., Ot.),

dok je u nekome duša 'dok je živ' - 'dopóki ktoś żyje' (Mat., Ot.),

došla duša nekome pod grlo (u nos) 1. 'biti na samrti' - 'umierać’; 2. 'teško disati

od umora' - 'ciężko dyszeć ze zmęczenia' (Mat., Ot.), dršće duša na jeziku 'biti na samrti' - 'umierać' (Mat.), duša je nekome na jeziku 'biti na samrti, umirati' - 'umierać' (Mat., Men., Ot., RSJ), duša je nekome u nosu 'biti teško bolestan' - 'być ciężko chorym' (Mat., Ot., RSJ), duša se nekome povratila 'oporaviti se, prikupiti snagu' - 'wróciły komuś siły życiowe' (Mat., Ot.), ispade nekome duša / ispustiti dušu 'umreti' - 'umrzeć' (Mat., Men., Ot.), istisnuti nekome dušu na grlo 'usmrtiti nekoga gušenjem' - 'udusić kogoś' (Mat., Ot.), izvaditi nekome dušu 'ubiti nekoga' - 'zabić kogoś' (Mat., Ot.), nanositi se duše 'dugo živeti' - 'długo żyć' (Ot.), nositi dušu u nosu 'biti jedva živ' - 'być ledwo żywym' (Mat., Ot.), ostavi ga duša 'umreti' - 'umrzeć' (Mat., Ot.), piti, sisati nekome dušu na pamuk (na slamku) 'stalno mučiti, maltretirati nekoga' - 'męczyć kogoś, maltretować' (Mat., Ot.), predati dušu (Bogu, Gospodu) 'umreti' - 'umrzeć' (Mat., Ot.), stoji nekome duša u grlu 'biti teško bolestan' - 'być ciężko chorym' (Mat., Ot.), ubiti dušu (u nekome) 'uništiti nekoga, prebiti' - 'zniszczyć kogoś' (Mat., Ot.), uzeti (nekome) dušu 'ubiti' - 'zabić kogoś' (Mat., Ot., RSJ), zapekla se duša u nekome 'živeti suviše dugo' - 'zbyt długo żyć' (Ot.), zastade nekome duša 'jako se uplašiti' - 'bardzo się przestraszyć' (Ot.).

2. Dusza jako symbol i pierwiastek dobra w człowieku i innych bytach, niekoniecznie ożywionych, pozytywnego stosunku do otoczenia, wrażliwości. Być bez duszy / bezdusznym - to metaforyczne określenie człowieka niewrażliwego na ludzką krzywdę. Miejsce lub przedmiot posiadające duszę, ma pozytywny wy- 
dźwięk, klimat, jest na swój sposób niezwykły, wyjątkowy (dom, meble, samochód $z$ dusza), co jest widoczne zwłaszcza we współcześnie tworzonych wyrażeniach:

biti bez duše (srca) 'biti bezosećajan' - 'być niewrażliwym' (Mat., Men., Ot., RSJ), biti duša nečega 'biti pokretač, izvor, pristalica' - 'być inicjatorem, źródłem czegoś' (Mat., Ot.),

dobar kao duša 'biti veoma dobar' - 'być bardzo dobrym' (Ot., An.),

dobiti dušu 'dobiti nešto intimno, prijatnu atmosferu' - 'stworzyć przyjemną atmosferę' (Ot., An., Men.),

govoriti iz duše 'govoriti iskreno' - 'mówić szczerze' (Ot.),

izgubiti dušu 1. 'zgrešiti' - 'zgrzeszyć'; 2. 'činiti nešto protiv svoje volje' - 'robić

coś wbrew sobie'; 3. 'postati neosetljiv za tuđu muku' - 'stać się niewrażli-

wym na ludzką krzywdę' (Mat., Ot., An.),

kazati, reći po duši 'govoriti iskreno' - 'mówić szczerze' (Mat., Ot.), mek kao duša 'veoma mek (hleb, sir)' - 'bardzo miękki, dobry (o chlebie, serze)'

(Ot., An.),

nemati duše 'biti bezosećajan' - 'być bezdusznym' (Mat., Ot., RSJ),

stajati kao bez duše 'biti nemoćan' - 'być bezsilnym' (Mat., Ot.),

uvući dušu u se 'postati neaktivan' - 'stać się biernym' (Ot., RSJ.).

3. Dusza jako niematerialny byt, odpowiedzialny za formułowanie myśli, pragnień, rozważań, podejmowanie decyzji, zobowiązań, a tym samym nadrzędny w stosunku do materialnego ciała. Określenie stosowane wymiennie z umyst, rozum, sumienie, wynika z łączenia pojęcia duszy z pojęciem świadomości, umysłu, co jest obecne w filozofii od starożytności - od Arystotelesa, a rozbudowane przez Kartezjusza. Dusza podejmuje wolne decyzje, kierując ciałem (dualizm natury ludzkiej):

biti jedno t(ij)elo i jedna duša 1. 'živeti s nekim u slozi’ - ‘żyć z kimś w zgodzie’;

2. 'imati vrlo slične stavove' - 'mieć podobne poglądy' (Mat., Men., Ot.),

biti na nečijoj duši 'biti na nečijoj brizi' - 'być odpowiedzialnym za kogoś lub coś' (Mat., Ot.),

cepati nekome dušu 'nanositi nekome oštar bol' - 'zadawać komuś ból' (Ot.), dati, založiti dušu 'jamčiti za nekoga, nešto' - 'gwarantować za kogoś lub za coś' (Mat., Ot., RSJ),

dirnuti, potresti nekoga do dna duše 'uzbuditi, dirnuti nekoga u velikoj meri' - 'wstrząsnąć kimś, wzburzyć w ogromnym stopniu' (Mat., Ot.),

dušom i tijelom 'potpuno, sasvim' - 'całkowicie, zupełnie' (Men.), dušom poteći 1. 'preuzeti odgovornost za sebe' - 'wziąć odpowiedzialność za siebie’;

2. 'uništiti, upropastiti nekoga (klevetom)' - 'rzucić na kogoś klątwę' (Ot.), dušu dao 'u svemu odgovara nekoj nameri' - 'coś odpowiada zamierzeniom' (Mat., Men., Ot.), gledati nekome u dušu 'pažljivo posmatrati, ispitivati' - 'przyglądać się uważnie, wypytywać' (Mat., Ot.), 
gori nekome duša za nečim 'silno želeti nešto, nekoga' - 'bardzo czegoś (lub kogoś) pragnąç' (Mat., Ot.),

gristi dušu nekome 'ljutiti, nervirati nekoga' - 'złościć kogoś' (Ot.),

ići, pasti na nečiju dušu 'biti odgovoran za neki loš posao' - 'być odpowiedzial-

nym za czyjąś krzywdęe' (Mat., Ot.),

imati nekoga na duši 'biti odgovoran za nečiju smrt' - 'być odpowiedzialnym za czyjąś śmierć' (Mat., Men., Ot., RSJ),

lako je nekome pri duši 'biti veseo' - 'być wesołym' (Mat., Men., Ot.),

mirne duše 'mirno, bez grižnje savesti' - 'spokojnie, bez wyrzutów sumienia'

(Mat., Men., Ot., RSJ),

na dnu duše 'potajano' - 'potajemnie' (Ot.),

nositi teško breme na duši 'biti odgovoran za nečiju smrt' - 'być odpowiedzial-

nym za czyjąś śmierć' (Mat., Men., Ot., RSJ),

ogriješiti dušu 'biti nepravedan prema komu' - 'być nieuczciwym wobec kogoś’

(Men.),

olakšati dušu 'utešiti se' - 'ucieszyć się' (Ot.),

otkriti dušu i srce 'pokazati svoja osećanja' - 'pokazać uczucia' (Mat., Ot., RSJ), pao je nekome kamen sa srca, duše, vrata 'osloboditi se nekih problema' - 'pozbyć

się kłopotów' (Mat., Ot., RSJ),

peče nekoga na duši 'biti loše volje, neraspoložen' - 'być źle usposobionym' (Mat., Ot.), popeti se nekome na dušu 'ugnjaviti nekoga' - 'męczyć kogoś, dręczyć' (Mat., Ot.), prozreti nekoga u dušu 'otkriti nečije namere' - 'przejrzeć czyjeś zamiary' (Mat., Ot.), spasti s duše 'prestati smetati nekome' - 'przestać komuś przeszkadzać' (Ot.), staviti nekome, nešto na dušu 'zadužiti nekoga' - 'zobowiązać kogoś do czegoś' (Mat., Men., RSJ),

teško je nekome pri duši 'imati neke probleme' - 'mieć jakiś problem' (Mat., Men., Ot.),

u dubini duše (srca) 'potajano' - 'skrycie', (Mat., Men., Ot., RSJ),

uhvatiti nekoga za dušu (srce) 'dopasti se nekome u velikoj meri' - 'spodobać się komuś' (Ot.),

uneti se (urezati se) nekome u dušu 'postati nekome drag' - 'stać się dla kogoś drogim' (Ot.),

uvrediti nekoga do dna duše 'uvrediti nekoga u velikoj meri' - 'bardzo kogoś urazić' (Mat., Ot.),

visiti o duši 'biti glavna, najveća briga' - 'być problemem, zmartwieniem' (Ot.), voleti (mrzeti, osećati) iz dubine duše (srca) 'u najvećoj meri voleti' - 'kochać w najwyższym stopniu' (Ot.),

znati nekoga u dušu 'znati vrlo mnogo o nekome' - 'wiedzieć dużo o kimś' (Mat., Men., Ot., RSJ),

Charakterystycznym aspektem wielu tych najliczniej reprezentowanych frazeologizmów jest wyraźnie zaznaczona „fizyczność”, materializacja duszy, na której można coś odcisnąć, wyryć, można ją czymś obciążyć, obarczyć lub zdjąć coś, 
gryźć, niszczyć, podobnie do pol. złamać komuś serce, zranić duszę. Jest to o tyle zaskakujące, że dusza w tych określeniach pełni funkcje pierwiastka o charakterze niematerialnym, duchowym, który odpowiada za nasze decyzje, sądy, myśli, emocje. Te głęboko fizyczne działania, którym może podlegać dusza, mają za zadanie zaakcentować złożoność tego elementu naszej natury, jego kruchość, delikatność, z jednej strony (duszę, psychikę ludzką łatwo można zniszczyć, złamać), ale też i siłę, wytrwałość, odporność na ból i na trudy.

W języku polskim jest mniej frazeologizmów ze składnikiem dusza, gdyż leksem ten jest często zastępowany wyrazem serce, co widać choćby na podstawie odpowiedników znaczeniowych przedstawionych powyżej przykładów: lako je nekome pri duši - lekko na sercu; cepati nekome dušu - ranić serce; na dnu duše - w głębi serca; spasti s duše - spadł (komuś) kamień z serca; teško je nekome pri duši - ciężko jest komuś na sercu / duszy; uhvatiti nekoga za dušu - ująć kogoś za serce; nemati duše - nie mieć serca.

4. Dusza jako metonimiczne określenie człowieka, jako wyznacznik i symbol człowieczeństwa, np. pol.: nie ma żywej duszy; dusza w tym kontekście znaczeniowym pojawia się też jako pieszczotliwe określenie (kobiety, dziecka) moja duszko; duszyczki, są to określenia na ogół o wydźwięku pozytywnym lub neutralnym:

ciganska duša 'osoba prljava, nepouzdana, bez karaktera' - 'osoba brudna, bez charakteru, fałszywa' (Mat., Men., Ot.),

čestita (plemenita, dobra) duša 'dobra, poštena osoba' - 'dobry, uczciwy człowiek' (Mat., Men., Ot.),

duša od čov(j)eka 'dobar čov(j)ek' - 'dobry człowiek' (Mat., Men., Ot., An.), kriva duša 'vampir, sablast, utvara' - 'wampir, zmora' (Mat., Ot.), krštena (rajska) duša 'hrišćanin, čovek uopšte' - 'chrześcijanin, człowiek w ogóle' (Ot., RSJ),

mrtve duše 'nepostojeće osobe' - 'osoby nieistniejące' (Men.), nema nigde ni krštene duše 'nikoga nema' - 'nikogo nie ma' (Ot.), ni žive duše nema ' nikoga nema' - 'nikogo nie ma' (Mat., Men.), nevina dušica (iron.) 'bezazlena osoba' - 'osoba naiwna' (Mat.), p(j)esnička duša 'čov(j)ek p(j)esničkih os(j)ećanja' - 'człowiek wrażliwy, poeta’ (Mat., Ot.),

prodana duša 'nekarakterna osoba, koja radi koristi napusti svoja uverenja' - 'osoba sprzedajna' (Ot., Men., RSJ.), sitna duša 'osoba uskih pogleda, sitničava osoba' - 'człowiek małostkowy, drobiazgowy' (Mat., Men.), srodna duša 'bliska osoba, sličnih pogleda' - 'osoba o podobnych poglądach' (Men.), široka duša 'altruista, nesebičan' - 'człowiek szczodry, altruista' (Mat., Ot.), 
Są to, w większości, określenia człowieka dobrego, uczynnego (nieliczne wyjątki: prodana, kriva, ciganska, sitna duša). Często w codziennym, potocznym języku, a także w piosenkach i pieśniach ludowych występuje zwrot $d u$ šo! do osób drogich naszemu sercu, ukochanej, dziecka: spavaj dušo; jedi dušo još malo; Maro! Dušo moja; Ti si Kato moja duša. Frekwencja tego użycia wydaje się być większa w językach serbskim i chorwackim niż w języku polskim, gdzie zwrot duszo! duszko! właściwie jest już archaizmem. Choć określeń tych nie możemy zaliczyć do frazeologizmów, warto o nich wspomnieć, bo wpisują się w kontekst znaczeniowy omawianej grupy.

Swoistą karierę w języku zrobiło też określenie martwe dusze pochodzące od tytułu powieści M. Gogola (opozycją do niego mogą być przytaczane wcześniej żywe dusze), którego to pojęcia pisarz użył na oznaczenie zmarłych chłopów pańszczyźnianych figurujących w rejestrach jako żyjący. We współczesnym języku ta, wydawałoby się, archaiczna przenośnia, jest dość dobrze rozumiana i wykorzystywana, zwłaszcza w języku prasowym, gdzie zauważalna jest obecność tego określenia - można nawet mówić o jego popularności wśród polskich publicystów. Świadczą o tym tytuły w prasie: Martwe dusze w Platformie. Co ustali prokurator ${ }^{1}$. Tzw. martwe dusze stały się charakterystycznym elementem nie tylko sceny politycznej, ale też naszego życia społecznego, bowiem mamy martwe dusze w szkołach, przedszkolach, służbie zdrowia i zapewne w wielu innych instytucjach ${ }^{2}$. Zjawisko to nieobce jest też serbskiej i chorwackiej scenie politycznej, choć trzeba dodać, że jego obecność w prasie codziennej ogranicza się raczej do spraw polityki: Mrtve duše živih poslanika ${ }^{3}$, Neke mrtve duše kod nas su glasovale na izborima ${ }^{4}$. Warto zwrócić uwagę, że w tym znaczeniu tylko słownik chorwacki A. Menac odnotowuje ten frazeologizm. Ponadto w języku serbskim i chorwackim określenie mrtve duše posiada też niejako swoje podstawowe, źródłowe znaczenie, odpowiadające pol.: dusze zmarlych, dusze zmarłe, za które odprawiane są nabożeństwa i modlitwy.

Podsumowując rozważania na temat duszy w języku i kulturze słowiańskiej, należy uznać wielopłaszczyznowość tego pojęcia. Sferą duchową człowieka zajmuje się wiele dziedzin nauki: filozofia, teologia, psychologia, kulturoznawstwo, etnologia; nie tylko nauki humanistyczne, także biologia, a nawet medycyna.

${ }^{1}$ http://wyborcza.pl/1,75478,10053898,Martwe_dusze_w_Platformie__Co_ustalil_ prokurator_html, (dostęp dnia: 25.03.2012)

${ }^{2}$ http://www.polskieradio.pl/5/3/Artykul/572586,Martwe-dusze-we-wroclawskich-szkolach

http://www.rynekzdrowia.pl/Finanse-i-zarzadzanie/Obietnice-oferentow-kontroleplatnika-czyli-martwe-dusze-i-inne-kontraktowe-fikcje,107712,1.html, (dostęp dnia: 25.03.2012),

${ }^{3}$ http://www.vreme.com/cms/view.php?id=319728, (dostęp dnia: 25.03.2012),

${ }^{4} \mathrm{http} / /$ www.vecernji.hr/scena/tarik-filipovic-neke-mrtve-duse-kod-nas-su-glasovaleizborima-clanak-338981, (dostęp dnia: 25.03 2012), 
Ilość znaczeń i zastosowań terminu dusza w języku jest imponująca i oddaje różne aspekty pojmowania duszy na przestrzeni dziejów, co starałam się wykazać w powyższych rozważaniach na bazie materiału z obszaru sztokawskiego. Jak pokazują to powyżej zaprezentowane związki frazeologiczne - leksem dusza może wnosić do nich rozmaite konotacje: może być symbolem życia, istnienia, być wyznacznikiem pewnych wartości etycznych, z czego wynika kolejny aspekt znaczeniowy - dusza jako „organ” odpowiedzialny za podejmowanie decyzji, ekwiwalent rozumu, świadomości. Dusza wraz z odpowiednimi określeniami, może też charakteryzować samego człowieka. Wiele z tych zastosowań ma już dziś wartość archaiczną, historyczną, co zbieżne jest $\mathrm{z}$ sytuacją $\mathrm{w}$ języku polskim. Inne z kolei przeżywają swoisty renesans (martwe dusze, dusza towarzystwa, bratnia dusza, dom z dusza).

\section{Literatura}

Arystoteles, O duszy, Warszawa 1988.

Chlebda W., Elementy frazematyki, Łask 2003.

Duch W., Duch i dusza, czyli prehistoria kognitywistyki, „Kognitywistyka i Media w Edukacji” 1, 1999, s. 7-38.

EJO 1995 - Encyklopedia językoznawstwa ogólnego, hasło: idiom (frazeologizm), red. K. Po lański, Wrocław, s. 215.

Gieysztor A., Mitologia Słowian, Warszawa 1986.

Moszyński K., Kultura ludowa Stowian, t. 2., Warszawa 1967.

Szyjewski A., Religia Stowian, Kraków 2003.

\section{Słowniki}

A nić V., Rječnik hrvatskoga jezika, Zagreb 1998.

Bąba S., Liberek J., Słownik frazeologiczny współczesnej polszczyzny, Warszawa 2003.

Kovačević Z., Srpsko-engleski rečnik idioma, izraza i izreka, Beograd 1991.

Matešić J., Frazeološki rječnik hrvatskoga ili srpskoga jezika, Zagreb 1982.

Menac A., Fink-Arsovski Z., Venturin R., Hrvatski frazeološki rječnik, Zagreb 2003.

Menac A., Pintarić N., Hrvatskosrpsko-poljski frazeološki rječnik, Zagreb 1986.

Müldner-Nieckowski P., Wielki słownik frazeologiczny języka polskiego, Warszawa 2003.

O tašević Đ., Mali srpski frazeološki rečnik, Belgrad 2007.

Rečnik srpskohrvatskog književnog i narodnog jezika, Beograd 1959-.

Rečnik srpskohrvatskoga književnog jezika, Novi Sad 1967-1976.

Rečnik srpskoga jezika, Novi Sad 2007. 
Źródła internetowe

http://wyborcza.pl/1,75478,10053898,Martwe_dusze_w_Platformie__Co_ustalil_prokurator_.html

http://www.rynekzdrowia.pl/Finanse-i-zarzadzanie/Obietnice-oferentow-kontrole-platnikaczyli-martwe-dusze-i-inne-kontraktowe-fikcje,107712,1.html

http://www.polskieradio.pl/5/3/Artykul/572586,Martwe-dusze-we-wroclawskich-szkolach http://www.vreme.com/cms/view.php?id=319728

http://www.vecernji.hr/scena/tarik-filipovic-neke-mrtve-duse-kod-nas-su-glasovale-izborimaclanak-338981

\section{About Slavic soul in beliefs, culture and language on the example of Shtokavian idioms}

\section{(Summary)}

The article is devoted to the issue of soul in language and culture of the Slavs. Analysis includes presentation of the phenomenon of soul in old Slavic beliefs and religion, before adoption of Christianity. Many of these beliefs is still present in Slavic culture and language, despite the acceptance of Christian soul conception.

Linguistic analysis is carried out on the Serbian and Croatian idioms with soul lexeme. Four semantic group were extracted:

1. Soul as a symbol of life, motion and elusiveness of life;

2. Soul as a symbol of good, positive energy;

3. Soul as a metaphor of awareness, brain responsible for deciding;

4. Soul as a human equivalent. 